\title{
Techno-economic Feasibility of Modified Pulse Arc Deposition on Thick Section of Quenched and Tempered Steel
}

\author{
Neville Cornish ${ }^{1 *}$, Rahim. Kurji ${ }^{1,}$, Anthony Roccisano ${ }^{2}$, and Reza Ghomashchi ${ }^{2}$, \\ ${ }^{1}$ Australian Welding Solutions,8/5 Stephen St, Melrose Park, South Australia, 5039 Adelaide, Australia \\ ${ }^{2}$ The University of Adelaide, Adelaide, Australia
}

\begin{abstract}
Quenched and Tempered (Q\&T) steels welded structures that have numerous applications, particularly in the defence industry. However these steels are particularly prone to Hydrogen Assisted Cold Cracking (HACC) and require a highly-skilled welder to fabricate defect-free structures. This is due to the selection of the manual metal arc welding process of shielded metal arc welding (SMAW). The introduction of Modified Pulsed arc mode of depositions; a variation to Pulsed Arc deposition, has advanced deposition rates and can be employed by welders with a greater variation in skill. In this body of work, full strength butt welds are fabricated on 20mm, sections of Q\&T AS/NZS 3597 Grade 700 steel under a high level of restraint using Modified Pulse Gas Metal Welding (GMAW-P) and conventional Shielded Metal Arc Welding (SMAW). The study investigates the economic feasibly of the two modes of deposition and the propensity for cracking when welded under high restraint. The study concluded that modified GMAW-P achieved reduction of $63 \%$ in the 'Arc-On' time and an $88 \%$ reduction in the total normalised fabrication time. However, due to the increased propensity to lack of fusion type defects, strict controls must be employed in optimising the welding procedure to mediate for such defects if GMAW-P is to provide a techno-economically beneficial alternative to conventional SMAW when welding Q\&T steels.
\end{abstract}

\section{Introduction}

Steels employed for defence purposes, particularly steels that are used for armoured purposes, must withstand non-conventional loading conditions from threats such as ballistic projectiles and explosions. Although much research is devoted to the development and testing of armour grade materials [1-3], high strength armour steels are still widely adopted for the fabrication of safetycritical structures in the defence industry $[4,5]$.

Quenched and tempered steels are particularly favoured because of their high hardness, superior toughness and high strength to weight ratio, in addition to their relatively good weldability [6-8]. Nevertheless, welding of Q\&T steels alters the material microstructure as the matrix phases transform when subject to the heat generated during welding $[8,9]$. The heat affected zone (HAZ) exhibits softening due to tempering $[1,10]$. This softened zone often exhibits low creep and fatigue properties and poor ballistic performance [11, 12] compromising the integrity of the structure. Additionally, like most high strength low alloy steels, Q\&T steels are susceptible to hydrogen-assisted cold cracking.

\section{Hydrogen Assisted Cold Cracking \\ HACC is generally accepted [13-31] as the phenomenological consequence of a critical}

concentration of hydrogen trapped in a susceptible microstructure subject to a threshold level of stress. Traditionally, hydrogen cracks have been known to manifest in the coarse-grained HAZ and are frequently described as toe cracking, root cracking or under-bead cracking, depending on the location of the crack [17]. HACC is commonly referred to as cold cracking, since the cracks develop when the weld metal cools below $500^{\circ} \mathrm{C}$. This gives the residual hydrogen enough time to diffuse and incubate at favourite locations within the welded structure $[13,17,27,28]$. The length of this incubation period depends on the interrelationship amongst the three critical factors of residual hydrogen concentration, microstructure and level of stress that influences the formation of a cold crack.

The presence of hydrogen cracks threatens the integrity of the ligament and consequently the integrity of the asset. This threat is exacerbated by the loading conditions that assets employed in the defence industry may encounter during their service life. The delayed nature of hydrogen on cracking demands that significant effort be employed during design of welding procedures and fabrication to minimise the susceptibility of weldment to HACC.

\section{Modified Pulse Gas Metal Arc Welding}

Shielded Metal Arc Welding (SMAW) is extensively used in the construction of combat platforms and 
structures fabricated from Q\&T steels [8, 9, 32-35]. To minimise, the risk of hydrogen cracking, low hydrogen consumables are employed. The vast selection of electrode compositions available allow for the design of welding procedure specifications (WPS) with optimised mechanical properties, such as strength and toughness $[36,37]$. Nevertheless, the SMAW process requires highly skilled labour $[38,39]$ and is an inherently slow welding process. These two factors limit productivity and increase the overall cost associated with fabrication [40-42].

To address the productivity-associated limitations there exists a need to examine the feasibility of an alternative welding process. In the context of the fabrication of safety-critical structures in the defence industry, Pulsed Gas Metal Arc Welding (GMAW-P) may be one such alternative. It is important to highlight that conventional Gas Metal Arc Welding (GMAW) is discounted because of the inability to control the characteristics of weld deposition independent of heat input [36, 43-46]. Pulsed gas metal arc welding, however, is an exception. Moreover, the introduction of high clock frequency controllers into welding devices has facilitated the precise control of essential pulsed arc parameters such as the level and duration of the background and pulsed currents, the current rise and drop rates as well as the pulse frequency [44, 47]. The controller's response allows for different regulation strategies and modulation types (I/I and U/I modulations) to be employed. This brings about high process stability, low-spatter droplet transfer and the ability to deposit weldments with strict control of the heat input [43, 44].

Synergic process variants such as Modified Pulse Arc, which involves a modified I-I-I-controlled, nonshort-circuiting pulse, integrates the characteristics of the classic pulse arc with those of the classic spray arc and are particularly beneficial for high productivity welding [44]. Nevertheless, published works examining the comparative gains in productivity when compared to SMAW are hard to find. Additionally, acknowledging the inherent risk of fusion type defects (lack of side wall, root and inter-pass fusion) common with GMAW, there is a need to compare not only productivity, but also the integrity of weldments deposited under a range of comparable conditions using similar consumables.

In this body of work the comparative differences in productivity, susceptibility to HACC and mechanical properties of weldments deposited using conventional SMAW and GMAW-P are investigated. The current article however reports on the productivity and HACC susceptibility of both welding process and detailed mechanical and microstructural analysis will be reported elsewhere [48].

\section{Methodology}

\section{Weldability Test Sequence}

A two-stage experimental program was undertaken to examine the techno-economic feasibility of employing GMAW-P over conventional SMAW when welding thick sections of Q\&T steel. The testing program was conducted on a $20 \mathrm{~mm}$ thick sections of AS/NZS 3597 Grade 700 (EN 10137-2 Grade S690Q) quenched and tempered steel over a typical heat input range that would be expected during industrial fabrication of safetycritical structures.

\section{Stage 1: Productivity Testing}

To establish the difference in arc time and total fabrication time between the two modes of deposition, multi-pass full strength single sided butt welds were deposited on coupons $150 \mathrm{~mm}$ in length and $50 \mathrm{~mm}$ in width. Three test welds were deposited per target heat input, and an average of the total time (TT) for deposition and the 'arc-on' time (AOT) were recorded and compared.

\section{Stage 2: Weldability Testing to establish comparative susceptibility to HACC.}

To establish the susceptibility to HACC, multi-pass welds were deposited on the MWIC weldability test (Fig.1 and Fig. 2) [20], using the same parameter range that was tested in Stage 1.

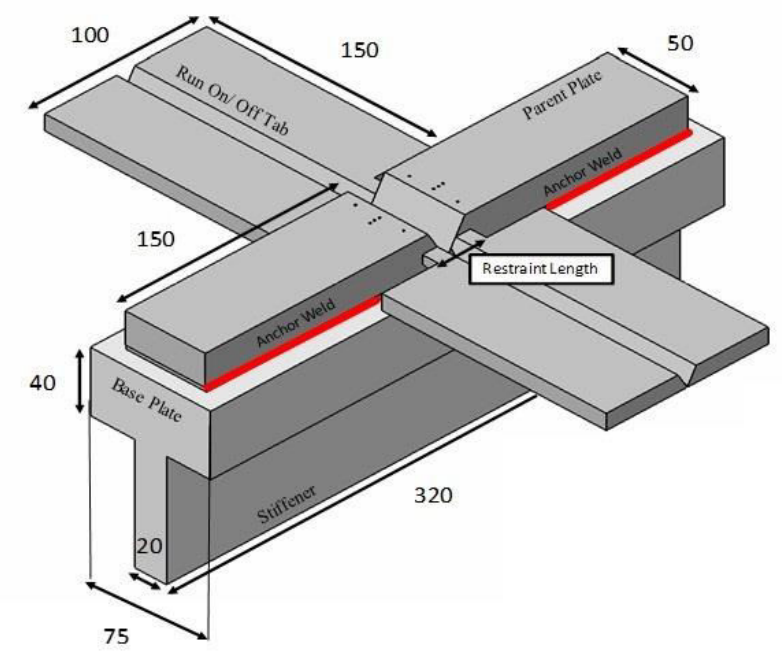

Fig.1. Dimensions of the MWIC Weldability Test. All dimensions in $\mathrm{mm}$. [20]

The welded joint was removed from the MWIC specimens 24 hours after weld completion by milling the test assembly just inside the restraint length. The anchor welds were sawed off using a Struers water-cooled precision metallographic saw. The weld zone was assessed for cracking by examining six weld metal transverse cross-sections prepared for metallurgical inspection (Figure 3) [20]. A sample is defined as cracked (Fig.4) if a planner defect is visually identified on a sample surface when magnified at $\mathrm{x} 400$, and the vertical length of the defect is greater than $5 \%$ of the height of the weld bead $\left(t_{\mathrm{w}}\right)$ [20]. The weld metal microstructure was examined using Zeiss Axio Imager optical microscope on metallographically prepared weldments cross-sections, (polished to $1 \mu \mathrm{m}$ diamond paste and etched in $2 \%$ nital solution). 


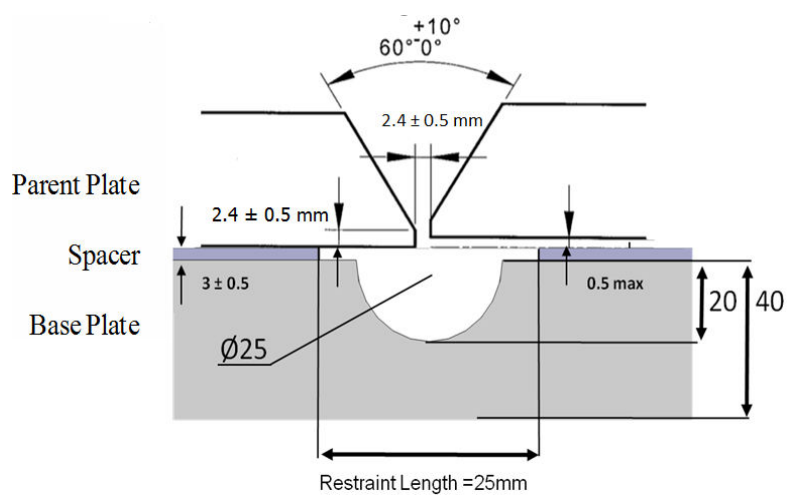

Fig. 2. Dimensions of the Single V Butt weld prep used for weldability testing. All dimensions in $\mathrm{mm}$ [20]

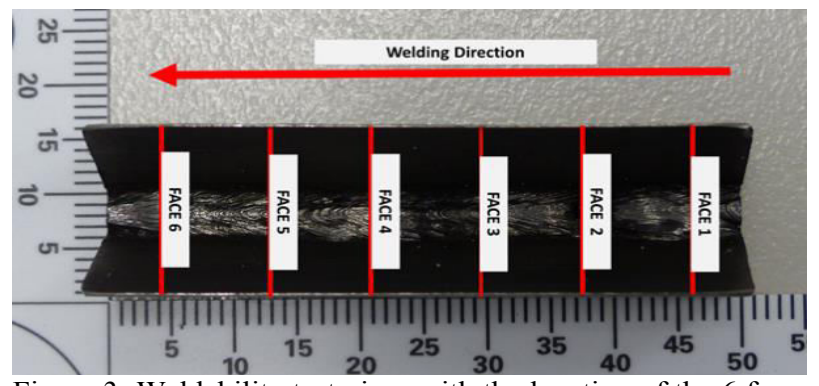

Figure 3: Weldability test piece with the location of the 6 faces to be examined under an optical microscope at a magnification of $x 400$ highlighted [20].

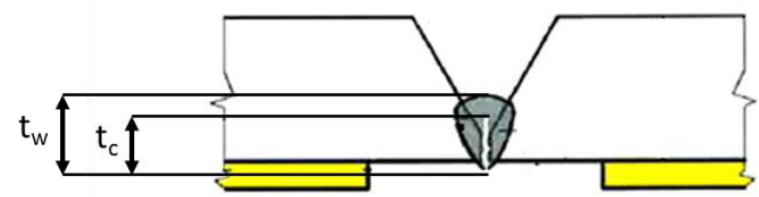

Fig.4. Schematic of a face of a test section. A sample is defined as cracked when a linear defect whose vertical length $\left(t_{c}\right)$ is greater than $5 \%$ of the bead height $\left(\mathrm{t}_{\mathrm{w}}\right)$. [20]

\section{Welding Parameter Selection and Control}

Weldability testing was carried out on a uni-directional, mechanised cradle (Lorch Track RL Pro) with the test specimen in a fixed horizontal position. For GMAW-P, the welding torch was secured in cradle and the trigger was manually operated to initiate and extinguish the welding arc (Fig. 5). For SMAW, the electrode holder was manually manipulated. The arm of the mechanised cradle was used as a guide to govern travel speed (Fig.6).

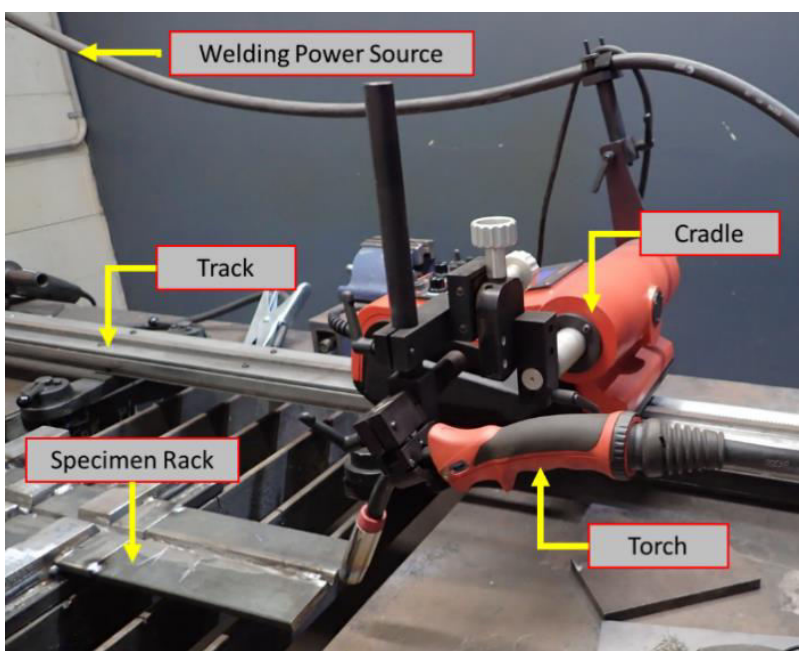

Fig. 5. Set up of weldability test cradle. The specimen racks were adopted to hold, $150 \mathrm{~mm}$ length coupons for productivity testing, MWIC weldability tests for HACC testing and $400 \mathrm{~mm}$ length sections for procedure qualification testing.

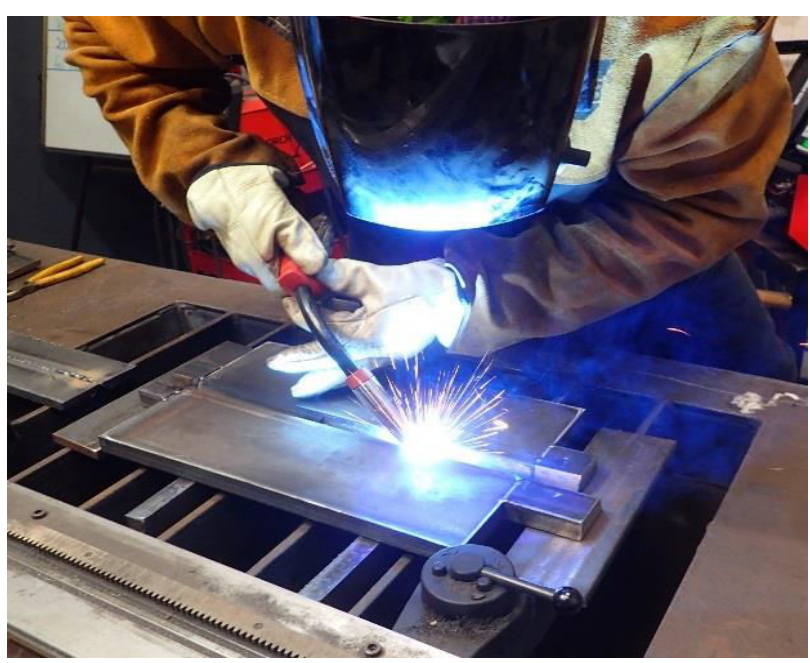

Fig.6. Procedure qualification testing, using non-mechanised deposition

The welding parameters employed during testing are summarised in Table 1 and Table 2 The Lorch S3 Speed XT was used as the welding power source.

Table 1, Welding Parameters -GMAW-P

\begin{tabular}{|l|l|l|l|}
\hline \multicolumn{2}{|l|}{ Welding Specifications } & \multicolumn{2}{l|}{ Welding Parameters } \\
\hline Direction & Flat $(1 \mathrm{G})$ & Current & $135-225 \mathrm{~A}$ \\
\hline $\begin{array}{l}\text { Diameter of } \\
\text { Wire }\end{array}$ & $1.2 \mathrm{~mm}$ & Voltage & $21-30 \mathrm{~V}$ \\
\hline AWS Class & A5.28 & Travel Speed & $\begin{array}{l}170- \\
400 \mathrm{~mm} / \mathrm{min}\end{array}$ \\
\hline Specification & ER 110S-G & $\begin{array}{l}\text { Heat Input } \\
\text { Range }\end{array}$ & $\begin{array}{l}0.48-2.19 \\
\mathrm{~kJ} / \mathrm{mm}\end{array}$ \\
\hline Polarity & DC+ Heat & $25^{\circ} \mathrm{C}$ \\
\hline $\begin{array}{l}\text { Shielding } \\
\text { Gas }\end{array}$ & $\begin{array}{l}\text { Pre } 18 \% \mathrm{CO}_{2} \\
\text { Range }\end{array}$ & $\begin{array}{l}\text { Deposition } \\
\text { Mode }\end{array}$ & $\begin{array}{l}\text { GMAW-P } \\
{[\mathrm{ISO} \quad 857} \\
\text { (Process No. } \\
13)]\end{array}$ \\
\hline
\end{tabular}


Table 2. Welding Parameters -SMAW

\begin{tabular}{|l|l|l|l|}
\hline \multicolumn{2}{|l|}{ Welding Specifications } & \multicolumn{2}{|l|}{ Welding Parameters } \\
\hline Direction & Flat (1G) & Current & $130-180 \mathrm{~A}$ \\
\hline $\begin{array}{l}\text { Size of } \\
\text { Electrode }\end{array}$ & $\begin{array}{l}3.2 \quad \text { \& } 4.0 \\
\text { Vm }\end{array}$ & Voltage & $21-25 \mathrm{~V}$ \\
\hline AWS Class & A5.5 & Travel Speed & $\begin{array}{l}80- \\
290 \mathrm{~mm} / \mathrm{min}\end{array}$ \\
\hline Specification & E11018M- & $\begin{array}{l}\text { Heat Input } \\
\text { Range }\end{array}$ & $\begin{array}{l}0.41-2.22 \\
\mathrm{~kJ} / \mathrm{mm}\end{array}$ \\
& $\mathrm{H} 4$ & $\begin{array}{l}\text { Pre Heat } \\
\text { Range }\end{array}$ & $25^{\circ} \mathrm{C}$ \\
\hline Polarity & DC+ & \\
\hline
\end{tabular}

\section{Material Specification}

The MWIC tests and procedure qualification test coupons were fabricated from AS/NZS 3597 Grade 700 (EN 10137-2 Grade S690Q) steel for the parent plate. Parent plate sections were cut from a single steel plate using the Techni INTEC- G2 1612 water jet. The cutting direction was oriented such that the prepared welding joint would remain perpendicular to the rolling direction of the plate, matching field conditions. The parent plate sections were then sandblasted in the ToolTec Sandblast SB-350 using glass beads with a diameter up to $305 \mu \mathrm{m}$, to remove any mill scale and/or surface contaminants. The groove surfaces of the test specimen and $25 \mathrm{~mm}$ either side of the weld centreline was polished down with ISO 80 grit $(201 \mu \mathrm{m})$ emery paper and degreased with acetone. The entire specimen was degaussed prior to welding. The parent plates and electrodes chemical compositions are given in Table 3, Table 4, and Table 5.

Table 3. Chemical Composition of Q\&T Steel (\% Weight) (From Manufacturer)

\begin{tabular}{|l|l|l|l|l|l|l|}
\hline $\mathrm{C}$ & $\mathrm{P}$ & $\mathrm{Mn}$ & $\mathrm{Si}$ & $\mathrm{S}$ & $\mathrm{Ni}$ & $\mathrm{Cr}$ \\
\hline 0.17 & 0.018 & 1.37 & 0.21 & 0.004 & 0.017 & 0.2 \\
\hline $\mathrm{Mo}$ & $\mathrm{Cu}$ & $\mathrm{Al}$ & $\mathrm{Sn}$ & $\mathrm{Ti}$ & $\mathrm{B}$ & $\mathrm{CE}($ IIW) \\
\hline 0.2 & 0.026 & 0.035 & 0.002 & 0.019 & 0.0017 & 0.4812 \\
\hline
\end{tabular}

Table 4. Electrode Batch Chemical Composition AWS A5.28, ER110S-G (\% Weight) (From Manufacturer)

\begin{tabular}{|l|l|l|l|l|l|l|}
\hline $\mathrm{C}$ & $\mathrm{Mn}$ & $\mathrm{Si}$ & $\mathrm{Ni}$ & $\mathrm{Cr}$ & $\mathrm{Mo}$ & $\mathrm{V}$ \\
\hline 0.09 & 1.6 & 0.5 & 1.4 & 0.3 & 0.25 & 0.09 \\
\hline
\end{tabular}

Table 5. Electrode Batch Chemical Composition AWS 5.5 E11018M-H4 (\% Weight) (From Manufacturer)

\begin{tabular}{|c|c|c|c|c|c|c|}
\hline $\mathrm{C}$ & $\mathrm{Mn}$ & $\mathrm{Si}$ & $\mathrm{P}$ & S & $\mathrm{Ni}$ & $\mathrm{Cr}$ \\
\hline 0.06 & 1.5 & 0.4 & 0.015 & 0.01 & 2.2 & $<0.15$ \\
\hline Mo & $\mathrm{V}$ & & & & & \\
\hline 0.4 & 0.08 & & & & & \\
\hline
\end{tabular}

\section{Results and Discussion}

\section{Speed Trials}

Speeds trials were conducted at three target heat inputs $(0.5,1.5$ and $2.0 \mathrm{~kJ} / \mathrm{mm})$, to simulate the widest practical range of heat inputs that would be encountered during the fabrication of safety-critical structures. As illustrated in Fig. 7, a maximum variation of $\pm 0.2 \mathrm{~kJ} / \mathrm{mm}$ was noted between the target heat input and the actual measured heat input over the range of heat input tests. Additionally, between welding processes a maximum variation of $4.26 \%$ was noted at the $0.5 \mathrm{~kJ} / \mathrm{mm}$ target.

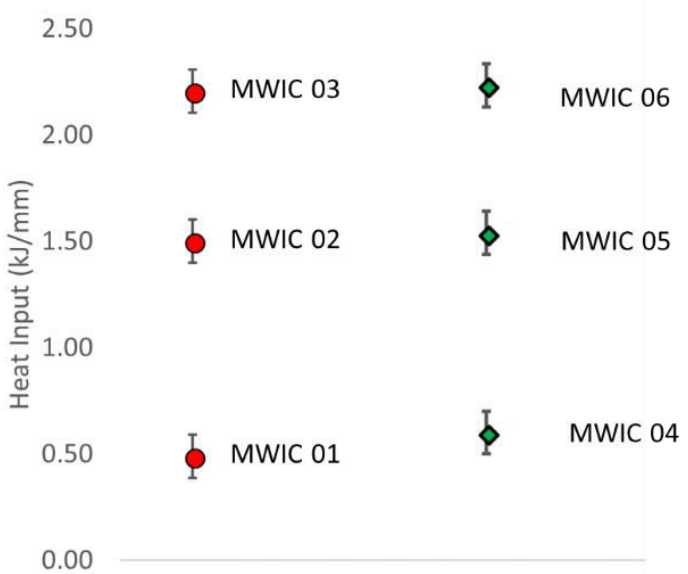

- Average Heat Input -GMAW-P $\diamond$ Average Heat Input SMAW

Fig. 7. Average heat input measured during Stage 1, productivity testing.

For the GMAW-P process, a change in heat input from $0.5 \mathrm{~kJ} / \mathrm{mm}$ to $1.5 \mathrm{~kJ} / \mathrm{mm}$ resulted in a $50 \%$ decrease in the number of weld runs deposited; increasing heat input from $1.5 \mathrm{~kJ} / \mathrm{mm}$ to $2 \mathrm{~kJ} / \mathrm{mm}$ resulted in a $17 \%$ reduction in the number of runs (Fig. 8). At a heat input of $2.5 \mathrm{~kJ} / \mathrm{mm}$, successful deposition was not possible because of consistent burn through.

For the SMAW process, a similar trend was noted, however the change in number of runs as a result of change in heat input was comparatively higher.

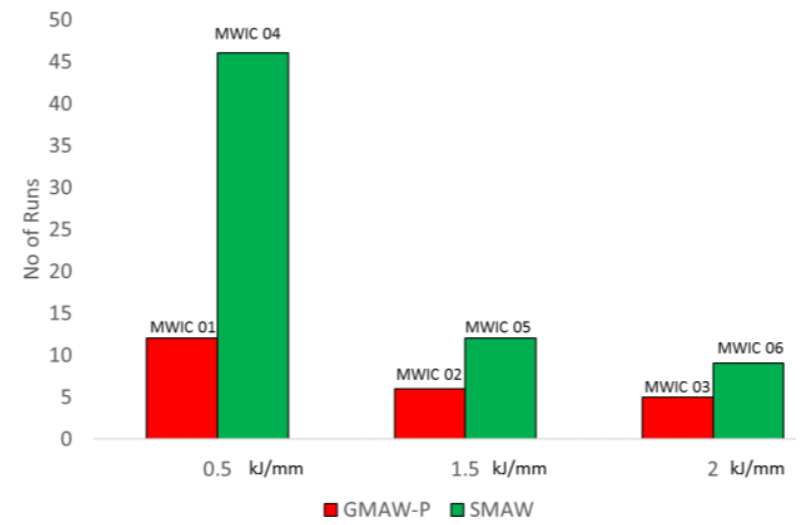

Fig. 8. Number of runs recorded at each target heat input for both GMAW-P and SMAW welding processes. For both welding processes the number of runs decreased proportionally to a change in the heat input.

For the SMAW process an increase in heat input from $0.5 \mathrm{~kJ} / \mathrm{mm}$ to $1.5 \mathrm{~kJ} / \mathrm{mm}$ resulted in a $74 \%$ reduction in the number of runs deposited. A further increase in heat input to $2.0 \mathrm{~kJ} / \mathrm{mm}$ resulted in a $25 \%$ reduction in the number of runs. When compared to the GMAW-P the relationship between number of runs deposited and heat input was nonlinear.

\section{Arc on Time (AOT)}

The effect of the number of runs deposited between each process on the total AOT is illustrated in Fig. 9. 


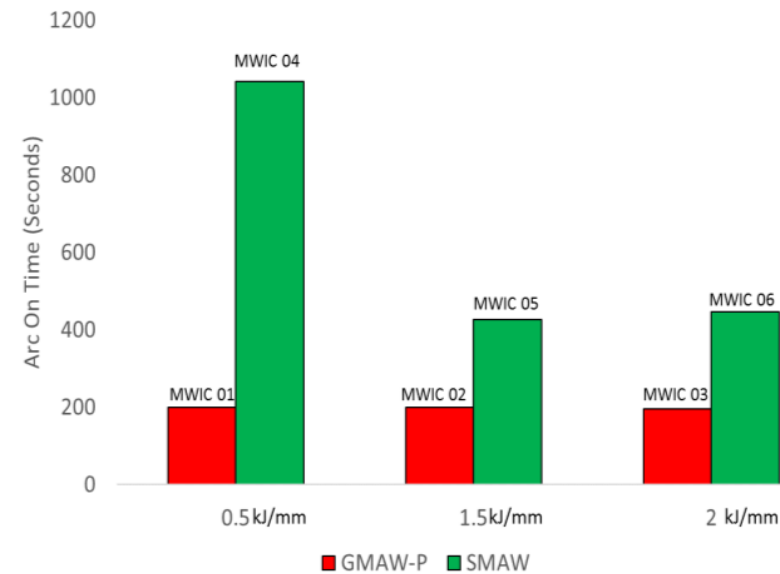

Fig. 9. Arc On time recorded at each target heat input for both GMAW-P and SMAW welding processes. For the SMAW welding processes, the arc on time decreased dramatically between 0.5 and $1 \mathrm{~kJ} / \mathrm{mm}$. For the GMAW welding process, there is a near negligible change in the arc on time as the heat input changed.

For the GMAW-P process, there is a near negligible change in the measured AOT as the heat input varied from 0.5 to $2.0 \mathrm{~kJ} / \mathrm{mm}$. This can be attributed to proportional increase in the size of weld bead with increasing heat input.

For the SMAW welding process, a change in heat input from $0.5 \mathrm{~kJ} / \mathrm{mm}$ to $1.5 \mathrm{~kJ} / \mathrm{mm}$ resulted in a decrease of $59 \%$ in the total AOT. A subsequent increase in heat input to $2.0 \mathrm{~kJ} / \mathrm{mm}$ resulted in a $5 \%$ decrease in AOT. When considering the geometry of the bead deposited, there is a significant difference in bead height and width between $0.5 \mathrm{~kJ} / \mathrm{mm}$ and $1.5 \mathrm{~kJ} / \mathrm{mm}$. For weld passes deposited at the low heat input of $0.5 \mathrm{~kJ} / \mathrm{mm}$, the weld bead width was narrow, and the crown of the bead pronounced. Subsequent passes had to be deposited in a sequence complementary to the existing profile without risking lack of inter-run fusion while maintaining high travel speeds to meet the target heat input. In addition to the lower volume of weld metal deposited at low heat inputs, the geometric characteristics of the deposited bead can also account for the significantly higher number of runs deposited and higher arc on time at the target heat input.

It must also be noted that higher energy in axial spray transfer inherent with the 92\% $\mathrm{Ar}+8 \% \mathrm{CO}_{2}$ shielding gas employed in the GMAW-P increases puddle fluidity and resulted in a flush face of the of the crown of the bead, allowing for optimisation of the weld sequence.

\section{Total Time (TT)}

Unlike arc on time which measures the time weld deposition is in progress, the Total Time (TT) in the context of this body of work, measures the time welding operation commenced to the time welding activities concluded. TT does not include preparation or tacking of the samples but does include inter-pass cleaning and changing of electrodes in the SMAW process (Fig.10).

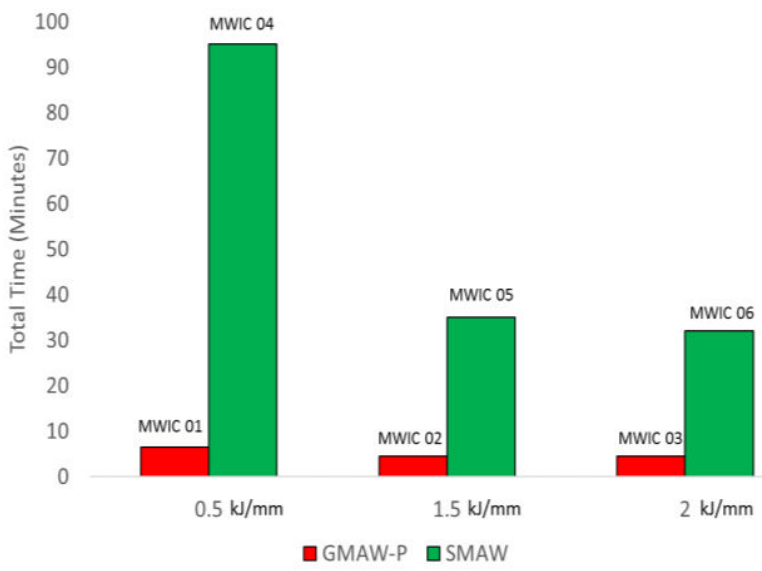

Fig.10. Total welding time recorded at each target heat input for both GMAW-P and SMAW welding processes. For the SMAW welding processes, the total welding time decreased dramatically between 0.5 and $1.5 \mathrm{~kJ} / \mathrm{mm}$. For the GMAW welding process, there is a near negligible change in the total welding time as the heat input changes.

As observed with the AOT, a change in heat input resulted in a marginal change in the total time for the GMAW-P process across the target heat input range. However, when comparing processes, as illustrated in Fig.10, a significant difference is noted in the total time taken to complete fabrication. On average at $0.5 \mathrm{~kJ} / \mathrm{mm}$ there was a $93 \%$ difference in the TT for deposition between the SMAW and GMAW-P process. For the heat input targets of 1.5 and $2.0 \mathrm{~kJ} / \mathrm{mm}$ there was a difference of $87 \%$ and $85 \%$ respectively.

\section{Productivity Gains}

From the speed trials there is sufficient evidence to surmise that the productivity gains, in terms of a) the reduction in the total number of runs required to complete the joints, b) the reduction in the arc on time as a result of the reduced number of runs and c) the total time saved from employing GMAW-P makes adoption of the welding of thick sections of Q\&T steels favourable. On average, a reduction of $63 \%$ in arc on time was noted over the heat input range tested and, a reduction of $88 \%$ in total deposition time. It is acknowledged that testing was conducted in the Flat (1G) position, however, the trials demonstrate that there is significant potential gain in productivity when employing modified pulsed gas metal arc welding.

\section{Weldability Trials}

To examine HACC susceptibly, transverse sections of welds deposited on the MWIC weldability test (Fig. 11) were examined under $\mathrm{x} 400$ optical magnification. 


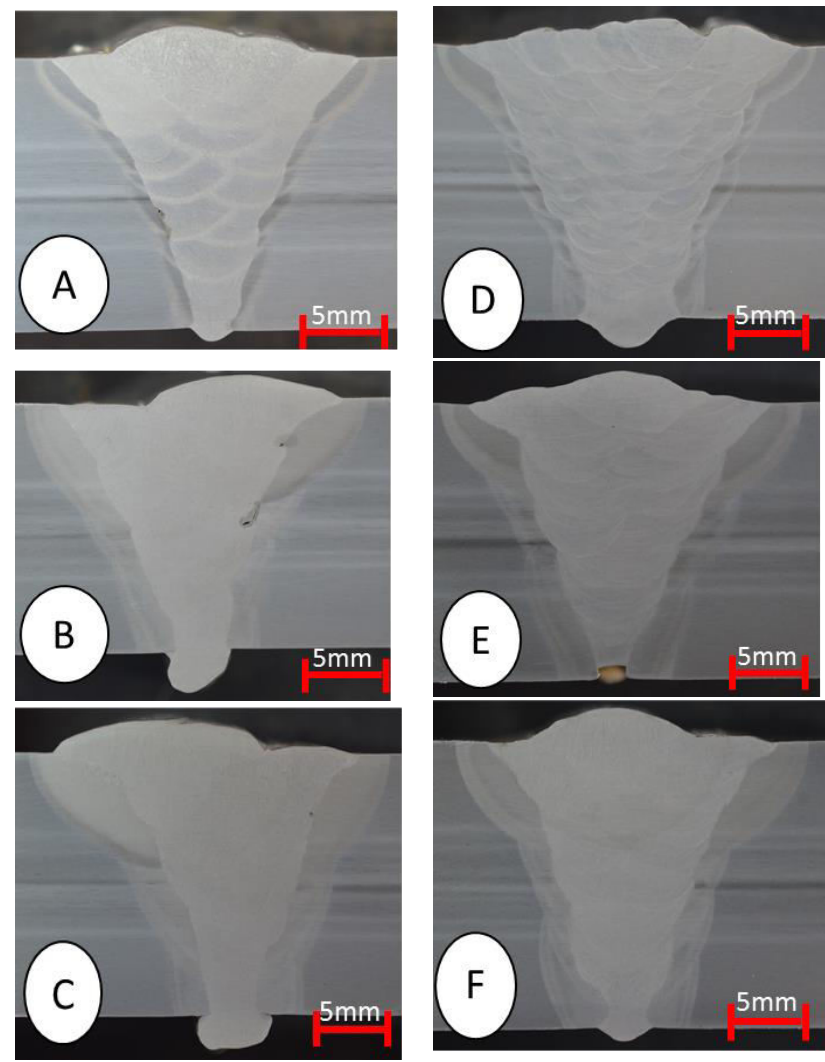

Fig. 11. Cross sectional macrographs from the MWIC samples. (A) MWIC 01 GMAW-P 0.5kJ/mm (B) MWIC 02 GMAW-P $1.5 \mathrm{~kJ} / \mathrm{mm}$ (C)MWIC 03 GMAW-P $2.0 \mathrm{~kJ} / \mathrm{mm}$ (D) MWIC 04 SMAW- $0.5 \mathrm{~kJ} / \mathrm{mm}$ (E)MWIC 05 SMAW $1.5 \mathrm{~kJ} / \mathrm{mm}$ (F) MWIC 06 SMAW-P $2.0 \mathrm{~kJ} / \mathrm{mm}$

The examination did not yield any evidence of hydrogen cracking, suggesting that under high levels of restraint, as simulated by the MWIC test, both processes were equally susceptible to hydrogen cracking.

There were a number of fusion defects identified in samples deposited using the GMAW-P process. As highlighted in Fig.12 and Fig. 13, there was evidence of lack of sidewall fusion for welds deposited at $0.5 \mathrm{~kJ} / \mathrm{mm}$ and $1.5 \mathrm{~kJ} / \mathrm{mm}$.

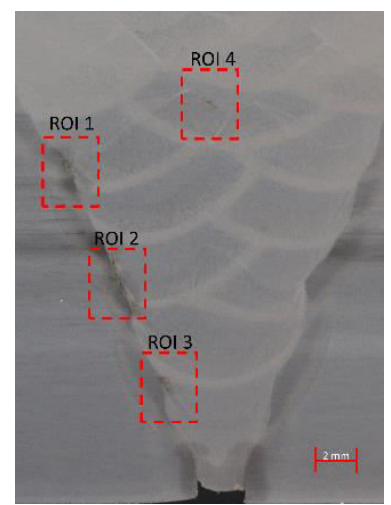

Fig.12. Lack of sidewall fusion (ROI 1-3) and Lack of inter-run Fusion (ROI 4), noted in MWIC 01, GMAW$\mathrm{P} 0.5 \mathrm{~kJ} / \mathrm{mm}$

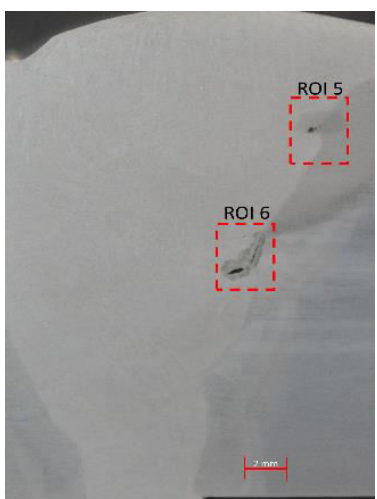

Fig. 13. Lack inter-run fusion and a slag inclusion (ROI 5) and Lack side wall fusion (ROI 6), noted in MWIC 02, GMAW-P $1.5 \mathrm{~kJ} / \mathrm{mm}$

\section{Microstructure}

The integrity of weld structure and mechanical properties is very much dependent on the microstructure and the morphology of the phases formed. The HAZ as it forms is fully bainitic but transforms to a mixture of bainite and polygonal ferrite and pearlite when the next few passes are deposited; an indication of tempering effect that the future passes have on the initial passes like the root pass (See Figure 14 for GMAW-P and SMAW taken from HAZ of root pass). The weld structure however is almost the same in both welding processes, but the scale of structure is slightly greater for the GMAW-P. This is probably due to the melt pool size which is larger for GMAW-P as could be seen in the macro-photographs in Figure 11. A more detailed microstructural analysis will be provided below [48].

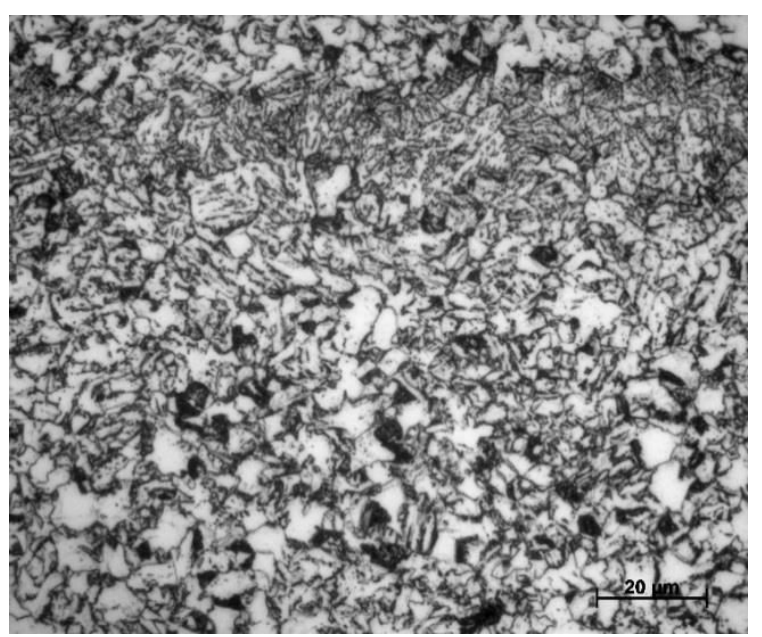

Fig. 14. HAZ-Centre Pass (GMAW-P), bainitic with some ferrite and pearlite

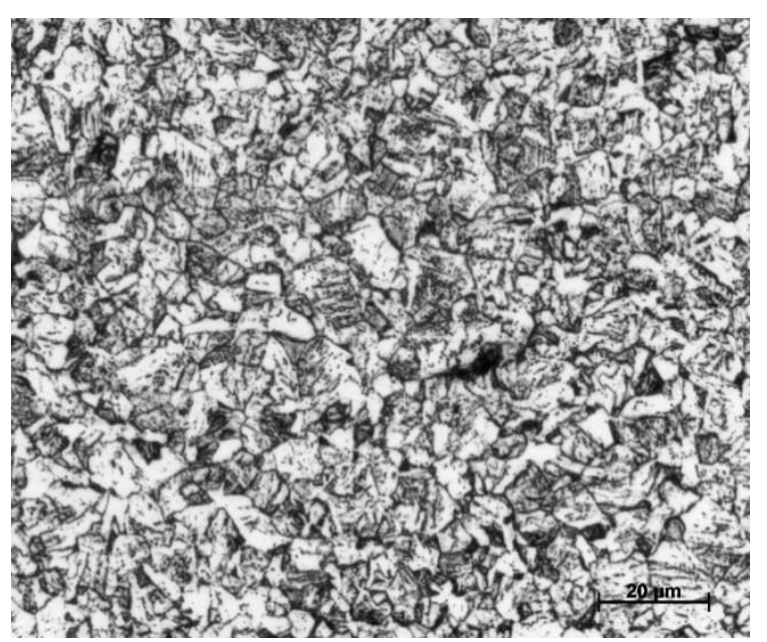

Fig. 15. HAZ-Centre pass (SMAW): bainitic with some ferrite and pearlite

Fig. 14 and Fig. 15 are optical micrographs taken from the HAZ of GMAW-P and SMAW welds to show the effect of weld pass deposition on microstructural changes. 


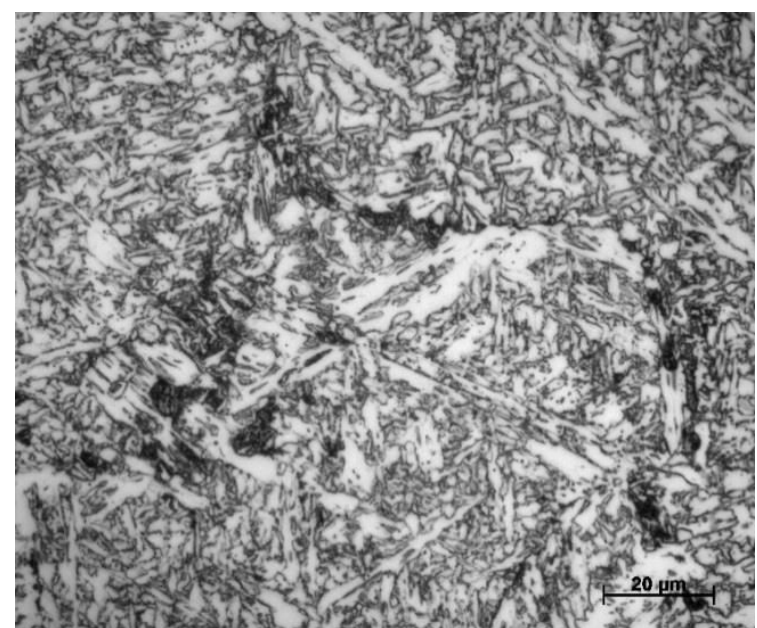

Fig. 16. Weld metal Centre, GMAW-P, the structure comprises acicular ferrite and bainite

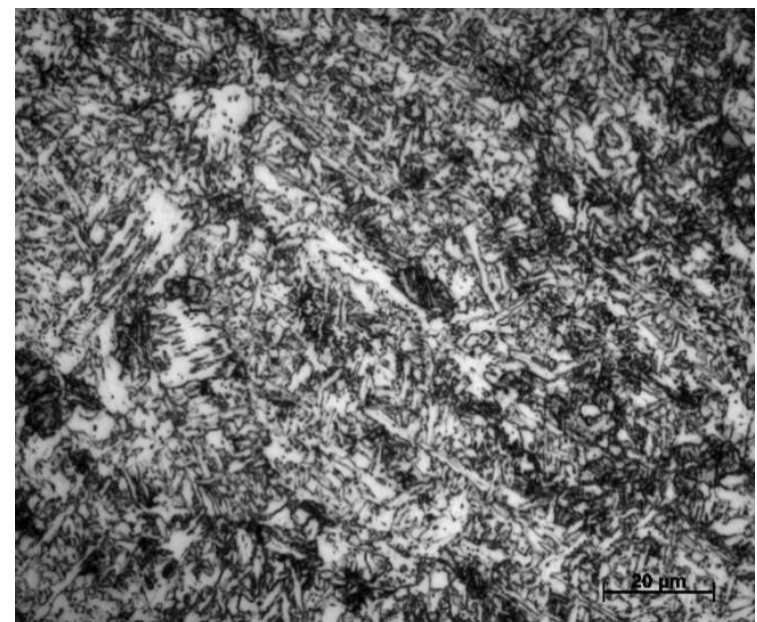

Fig.17. Weld metal structure-Centre- SMAW, the structure comprises acicular ferrite and bainite

Fig. 16 and Fig.17 are optical micrographs taken from the weld metal of GMAW-P and SMAW welds to show the effect of weld process on microstructural.

\section{Conclusions}

The techno-economic feasibility of Modified Pulse Gas Metal Arc Welding for the welding of thick sections of Quench and Tempered (AS/NZS 3597 Grade 700) steels was assessed by comparing deposition rates, susceptibility to Hydrogen Assisted Cold Cracking and mechanical test results for a range of heat inputs to the conventional Shielded Metal Arc Welding process.

Productivity trials demonstrated that for the heat input range tested $(0.5-2.0 \mathrm{~kJ} / \mathrm{mm})$ there was on average a reduction of $63 \%$ in the 'Arc-On' time and an $88 \%$ reduction in the total normalised fabrication time.

Weldability testing on the MWIC test demonstrated that for the filler materials selected (E11018M-H4 and ER 110S-G), within the target heat input range, under high restraint $(\mathrm{Rf}=25 \mathrm{~mm})$ the GMAW-P did not exhibit an increased susceptivity to cracking. However, welds deposited using GMAW-P were prone to lack of sidewall fusion and lack of interrun fusion.
More work is required to demonstrate productivity improvement while maintaining dependability in the deposition homogeneous weldments with gas shielded wire processes. Confidence in the process is required to consider code acceptance.

The research work was funded by Australian Welding Solutions. The authors would like to thank Damien Lynch, for his time and expertise.

\section{References}

1. Falkenreck, T., A. Kromm, and T. Böllinghaus, Investigation of physically simulated weld HAZ and CCT diagram of HSLA armour steel. Welding in the World, 2018. 62(1): p. 47-54.

2. Chin, E.S., Army focused research team on functionally graded armor composites. Materials Science and Engineering: A, 1999. 259(2): p. 155161.

3. Schuldies, J. and R. Nageswaran, Ceramic matrix composites for ballistic protection of vehicles and personnel, in Blast Protection of Civil Infrastructures and Vehicles Using Composites. 2010, Elsevier. p. 235-243.

4. Czyryca, E. Advances in high strength steel technology for naval hull construction. in Key Engineering Materials. 1993. Trans Tech Publ.

5. Pussegoda, L.N., B.A. Graville, and L. Malik, Delayed cracking in naval structures steels. 1997, Department of National Defence, Canada: Ottawa, ON.

6. Ade, F., Ballistic qualification of armor steel weldments. Welding Journal, 1991. 70(9): p. 53-58.

7. Magudeeswaran, G., et al., Effect of welding processes and consumables on tensile and impact properties of high strength quenched and tempered steel joints. Journal of iron and steel research, international, 2008. 15(6): p. 87-94.

8. Magudeeswaran, G., V. Balasubramanian, and G.M. Reddy, Hydrogen induced cold cracking studies on armour grade high strength, quenched and tempered steel weldments. International journal of hydrogen energy, 2008. 33(7): p. 1897-1908.

9. Magudeeswaran, G., V. Balasubramanian, and G.M. Reddy, Effect of welding processes and consumables on fatigue crack growth behaviour of armour grade quenched and tempered steel joints. Defence Technology, 2014. 10(1): p. 47-59.

10. Hochhauser, F., et al., Influence of the soft zone on the strength of welded modern HSLA steels. Welding in the World, 2012. 56(5-6): p. 77-85.

11. Hanhold, B., S. Babu, and G. Cola, Investigation of heat affected zone softening in armour steels Part 1-Phase transformation kinetics. Science and Technology of Welding and Joining, 2013. 18(3): p. 247-252.

12. Hanhold, B., S. Babu, and G. Cola, Investigation of heat affected zone softening in armour steels Part 2-Mechanical and microstructure heterogeneity. 
Science and Technology of Welding and Joining, 2013. 18(3): p. 253-260.

13. Yurioka, N., Predictive methods for prevention and control of hydrogen assisted cold cracking, in First International Conference on Weld Metal Hydrogen Cracking in Pipeline Grith Welds. 1999: Wollongong, Australia.

14. Yurioka, N., Weldability of modem high strength steels, in 1st US-Japan Symposium on Advances in Welding Metallurgy. 1990: San Francisco, CA. p. $79-100$.

15. Yurioka, N., S. Ohshita, and H. Tamehiro, Study on Carbon Equivalents to Assess Cold Cracking Tendency and Hardness in Steel Welding, in Conference on Pipeline Welding in 80's. 1981: Melbourne.

16. Yurioka, N., et al., Welding Note 3rd Edition. 1985, Kanagawa Japan: Nippon Steel.

17. Yurioka, N. and H. Suzuki, Hydrogen assisted cracking in C-Mn and low alloy steel weldments. International Materials Reviews, 1990. 35(4): p. 217 - 249.

18. Yurioka, N., S. Yamasaki, and H. Morimoto, Hydrogen effusion from high strength weld metal. Science and Technology of Welding and Joining, 2005. 10(4): p. 497-502.

19. Kurji, R. and N. Coniglio, Towards the establishment of weldability test standards for hydrogen-assisted cold cracking. The International Journal of Advanced Manufacturing Technology, 2015. 77(9-12): p. 1581-1597.

20. Kurji, R., et al., Modified WIC test: an efficient and effective tool for evaluating pipeline girth weldability. Science and Technology of Welding and Joining, 2016: p. 1-13.

21. Bailey, N., et al., Welding without hydrogen cracking. 2nd Edition ed. 1995, Cambridge: TWI, Abington Publishing.

22. Baker, R.G. and F. Watkinson, The effect of hydrogen on the welding of low-alloy steels, in Hydrogen in Steel. 1961, Iron and Steel Institute. p. 123 - 132.

23. Beacham, E.P., H.H. Johnson, and R.D. Stout, Hydrogen and delayed cracking in steel weldments. Welding Research Supplement, 1961. 40(4): p. 155 -159 .

24. Beachem, C., A new model for hydrogen-assisted cracking (hydrogen "embrittlement"). Metallurgical transactions, 1972. 3(2): p. 441-455.

25. Birnbaum, H., et al. Mechanisms of hydrogen related fracture--a review. in Second International Conference on Corrosion-Deformation Interactions. CDI'96. 1996.

26. Birnbaum, H.K. and P. Sofronis, Hydrogenenhanced localized plasticity - a mechanism for hydrogen-related fracture. Materials Science and Engineering: A, 1994. 176(1-2): p. 191-202.

27. Coe, F.R., Welding Steels without Hydrogen Cracking. 1973, Abington: The Welding Institute Report.
28. Coe, F.R., The Avoidance of Hydrogen Cracking in Welding. 1973, Abington: The Welding Institute Report.

29. Gedeon, S.A. and T.W. Eagar, Assessing Hydrogen-Assisted Cracking Fracture Modes in High-Strength Steel Weldments. Welding Journal, 1990. 69(6): p. 213s-220s.

30. Hirth, J.P., Theories of hydrogen induced cracking of steels, in Hydrogen embrittlement and stress corrosion cracking, R. Gibala and R.F. Hehemann, Editors. 1984: USA. p. 29 - 41.

31. Homrossukon, S., S. Mostovoy, and J.A. Todd, Investigation of Hydrogen Assisted Cracking in High and Low Strength Steels. Journal of Pressure Vessel Technology, 2009. 131(4): p. 041405041405.

32. Chen, L., Characterisation of transverse cold cracking in weld metal of a high strength quenched and tempered steel. 2000.

33. Datta, R., et al., Weldability characteristics of shieled metal arc welded high strength quenched and tempered plates. Journal of Materials Engineering and Performance, 2002. 11(1): p. 5 10.

34. Powell, G., et al. Cold cracking and segregation in multipass welds of a quenched and tempered steel. in International Conference on Trends in Welding Research (6th: 2002: Phoenix, Ariz. USA.). 2002.

35. Sterjovski, Z., Investigation of postweld heat treatment of quenched and tempered pressure vessel steels. 2003, University of Woolongong: Wollongong, NSW, Australia.

36. Linnert, G.E., Welding Metallurgy. 4th ed. Vol. 1. 1994, Miami, Florida: AWS.

37. Granjon, H., Fundamentals of welding metallurgy. 1991: Woodhead Pub Limited.

38. Chu, W.-H. and P.-C. Tung, Development of an automatic arc welding system using SMAW process. The International Journal of Advanced Manufacturing Technology, 2005. 27(3-4): p. 281287.

39. Byrd, A., R. Anderson, and R. Stone, The Use of Virtual Welding Simulators to Evaluate Experienced Welders. Welding Journal, 2015. 94(12): p. 389.

40. Funderburk, R.S., Key concepts in welding engineering. Welding Innovation, 1999. 16(1): p. 14.

41. Parmar, R., Welding engineering and technology. 2010: Khanna publishers.

42. Jeffus, L., Welding: principles and applications. 2011: Nelson Education.

43. Norrish, J., Recent gas metal arc welding (GMAW) process developments: the implications related to international fabrication standards. Welding in the World, 2017. 61(4): p. 755-767.

44. Jaeschke, B., Overview of the process control variants available in GMAW, in 2016, Lorch: Auenwald, Germany.

45. Norrish, J. Process control and automation developments in welding. in 8th Int. Conf. on Trends in Welding Research. ASM. 2009. sn. 
46. Ponomarev, V., et al., Metal transfer modes in $\mathrm{mig} / \mathrm{mag}$ (gmaw) welding: Contributions to a New IIW Classification. IIW Doc, 2009. 12: p. 1960-09.

47. Cramer, H., et al. Overview of modern arc processes and their metal transfer methods in the case of GMA welding. in The 6th International Conference-Innovative technologies for joining advanced materials. Timisoara, June 14-15. 2012.

48. Cornish, N. et al, "GMAW-P vs SMAW; microstructure and weld metal integrity", to be published, 2018 